\title{
Sistem Dakwah Pondok Pesantren At-Tawazun dalam Mengatasi Problematika Santri
}

\author{
Iyam Marhamah ${ }^{1 *}$ \\ Jurusan Manajemen Dakwah1, Jurusan Komunikasi Penyiaran Islam2, UIN Sunan Gunung \\ Djati, Bandung \\ *Email:Iyammarhamah.fidkom@gmail.com
}

\begin{abstract}
This paper aims to describe the da'wah system of At-Tawazun Islamic Boarding School through an open system starting from the input, conversion, output, feedback, and environment stages in an effort to overcome the problems of santri that are influenced by the times. This research uses case study method with qualitative approach and field research specification (field research). The results of this study indicate that the existence of the At-Tawazun Islamic Boarding Scool was felt to be of considerable benefit by parent and community. This da'wah and education institution has contributed to tackling social problems and juvenile delinquency that are increasingly complicated, so as to be able to provide graduates who are morally, virtous and able to practice their knowledge in the community, moreover, the presence of the AtTawazun Islamic Boarding School is expected to overcome the deviant cultural acculturation in the present era. So that the spirit of our young generation can be channeled suddenly to positive things, for the advancement of Religion and the state.
\end{abstract}

Keywords: Boarding School, Da'wah System, Problems, Santri

\begin{abstract}
ABSTRAK
Tulisan ini bertujuan untuk menggambarkan sistem dakwah Pondok Pesantren At-Tawazun ditinjau melalui sistem terbuka mulai dari tahap input, conversion, output, feedback, hingga environmentdalam upaya mengatasi problematika santri yang dipengaruhi oleh perkembangan zaman. Penelitian yang dilakukan ini menggunakan metode studi kasus dengan pendekatan kualitatifdan spesifikasi penelitian field research (penelitian lapangan). Hasil penelitian ini menunjukkan bahwa keberadaan pondok pesantren At-Tawazun dirasakan cukup besar manfaatnya oleh orang tua maupun masyarakat. Lembaga dakwah dan pendidikan ini telah ikut berkontribusi dalam menanggulangi masalah sosial dan kenakalan remaja yang semakin rumit, sehingga mampu memberikan lulusan santri yang brakhlak, berbudi luhur dan mampu mengamalkan ilmunya di masyarakat. Lebih dari itu, kehadiran pondok pesantren At-Tawazun diharapkan dapat mengatasi akulturasi budaya yang menyimpang di era sekarang ini.
\end{abstract}


Sehingga semangat generasi muda kita dapat disalurkan terhadak hal-hal positif, untuk kemajuan Agama dan Negara.

Kata Kunci: Sistem Dakwah Pondok Pesantren; Problematika; Santri

\section{PENDAHULUAN}

Islam adalah agama dakwah artinya agama yang selalu mendorong pemeluknya senantiasa aktif melakukan kegiatan dakwah. Maju mundurnya umat Islam sangat bergantung dan berkaitan erat dengan kegiatan dakwah yang dilakukannya, karena itu Al-Qur'an dalam menyebut kegiatan dakwah dengan Absanu Qaula. Menurut Muhammad Sayyid Wakil, dakwah adalah menghimpun manusia pada kebaikan dan memberi petunjuk kepada mereka atas hidayah dengan amar ma'ruf nahyi munkar untuk mensosialisasikan ajaran Islam kepada segenap umat manusia agar mereka mendapat kebahagiaan dalam hidupnya di dunia dan di akhirat kelak. Dari pengertian tersebut menggambarkan bahwa dakwah itu merupakan konsep yang global dan bertujuan sangat ideal (Ardi, D.M., 2015:4 dan 5).

Dakwah dalam ajaran Islam bertujuan untuk mempengaruhi dan mentransformasikan sikap batin dan perilaku warga masyarakat menuju suatu tatanan kesalahan individu dan kesalahan sosial. Dakwah dengan pesan-pesan keagamaan dengan pesan-pesan sosialnya juga merupakan ajakan kepada kesadaran untuk senantiasa memiliki komitmen (istigomab) di jalan yang lurus. Dakwah ajakan yang dilakukan untuk membebaskan individu dan masyarakat dari pengaruh eksternal nilai-nilai syaithaniyah dan kejabiliahan menuju internalisasi nilai-nilai ketuhanan. Di samping itu, dakwah juga bertujuan untuk meningkatkan pemahaman keagamaan dan berbagai aspek ajarannya agar diaktualisasikan dalam bersikap, berfikir dan bertindak.

Melihat fenomena yang terjadi di era globalisasi sekarang ini, banyak kita saksikan tingkah laku remaja yang bertentangan dengan norma hukum dan norma agama, seperti mabuk-mabukan, perkelahian, perkosaan, perjudian, bahkan sudah ada yang menjurus kearah pembunuhan. Sehingga mengakibatkan para orang tua dan seluruh masyarakat khawatir dengan keterlibataan remaja pada perilaku-perilaku yang bertentangan tersebut.

Pondok pesantren sebagai suatu wadah pendidikan merupakan komunitas dan masyarakat yang penuh dinamika. Kehidupan di suatu lingkungan pondok pesantren layaknya kehidupan dalam keluarga besar, yang seluruh anggotanya atau individu-individu di dalamnya harus berperan serta dalam menciptakan keharmonisan. Dinamika masyarakat pesantren tidak lepas dari pola hubungan sosial yang terjadi antar anggota masyarakat pesantren tersebut, khususnya antar sesama anak pesantren, atau biasa disebut "santri".

Santri sebagaimana dia seorang remaja, mengalami periode transisi perkembangan antar masa kanak-kanak dengan masa dewasa yang melibatkan 
perubahan-perubahan biologis, kognitif, dan sosio-emosional yakni untuk mempersiapkan diri memasuki masa dewasa dan masa depan. Sedangkan yang berkaitan dengan orang diluar keluarganya, seperti teman sebaya atau significant other lainnya.Dalam dunia pesantren, yang masuk dalam kategori remaja adalah santri yang berkategorikan usia sekitar 12-20 tahun (Effendi dan Ernawati, 2005). Santri juga sosok remaja yang memilik rasa persaudaraan yang kuat antar sesama teman. Hal ini disamping adanya doktrin agama untuk selalu menjaga ukhuwah Islamiyah juga kehidupan santri yang jauh dari orang tua yang mengharuskannya untuk hidup bersama sebayanya di pesantren.

Lembaga pendidikan seperti pondok pesantren, para santri di didik ilmuilmu keagamaan untuk menguatkan daya hati nurani mereka dengan keimanan untuk menuju hal-hal yang baik. Bukan hanya mengaji atau sekolah saja akan tetapi peraturan yang mengikat mereka pun yang mendidik mereka untuk selalu disiplin, patuh dan taat serta berkelakuan sesuai dengan ajaran agama islam.

Fungsi pesantren, selain sebagai lembaga pendidikan juga berfungsi sebagai lembaga social dan penyiaran agama Islam. Sebagai lembaga sosial misalnya, pesantren telah menampung berbagai santri yang berasal dari berbagai lapisan masyarakat. Semua santri disatukan dalam satu asrama atau pondok tanpa membeda-bedakan latar belakang, atau asal daerah masing-masing. Kemudian pesantren sebagai penyiaran agama dilihat dari fungsi pesantren sebagai tempat belajar agama islam dan tempat diselenggarakannya pengajian mingguan, bulanan, atau tempat diadakannya kegiatan-kegiatan keislaman bagi santri maupun bagi masyarakat umum (Matuhu, 1995:145).

Pondokpesantren At-Tawazunmerupakan sebuah lembaga pendidikan islam modern dengan jumlah santri sekitar 342 orang. Pesantren ini dibangun atas dasar kesepakatan bersama masyarakat desa kalijati dengan pimpinan yang bertujuan untuk membimbing,membina dan mengarahkan mereka khususnya para remaja agar segala tingkahlakunya sesuai dengan ajaran agama islam. Meskipun mereka santri, dan sama seperti remaja lainnya. Para santri inipun mengalami hal-hal yang lazimnya dialami oleh seorang remaja sehingga mereka melampiaskan dengan hal-hal yang melanggar peraturan-peraturan yang berlaku di pesantren.

Adapun beberapa kenalakan atau problem yang sering terjadi dikalangan santri di pondok pesantren At-Tawazun yaitu seringnya para santri melanggar peraturan atau tata tertib pesantren yang telah ditetapkan seperti tidak shalat berjamaah, kurangnya disiplin waktu, membawa hp, merokok, pacaran dan sebagainya. Permasalahan santri di pesantren sebenarnya bukan hanya itu, menurut Yuliati Hotifah(2015: 176) terdapat kompleksitas permasalahan santri yang merupakan suatu keniscayaan yang tidak dapat dielakkan. Permasalahan yang dihadapi santri tidak hanya aspek pembelajaran saja tetapi juga aspek 
pribadi sosial. Selain itu juga berkaitan dengan belum kuatnya pengetahuan agama dalam negokohkan kendali diri sehingga kepribadian menjadi rapuh (Tajiri, 2016).

Hal seperti Ini merupakan sebuah tantangan yang besar bagi pesantren AtTawazun dalam mendidik santri agar mereka senantiasa disiplin dan memenuhi tata tertib yang berlaku di pesantren serta berkelakuan baik sesuai dengan ajaran agama Islam. Bagi pesantren penanaman nilai karakter sudah teruji dalam sejarah, terutama penanaman nilai disiplin melalui sistem yang dimiliki pesantren (Tajiri, 2015 ). Pembinaan pesantren memiliki ciri berbasis motivasi keagamaan (Fitriyah dkk. 2018). Penanaman karakter dalam sistem pesantren menggunakan metode nasehat, keteladanan guru, bimbingan dan pendampingan, praktek dan pembiasaan amalan ibadah, pelurusan motivasi, koordinasi dengan wali santri, koordinasi dengan stakeholder dayah, out put pembinaan akhlak dan reward serta punishment (Rizal, M. dkk.,2018); menggunakan pendekatan menyeluruh, melalui pembelajaran, kegiatan ekstrakulikuler, pembiasaan, serta kerjasama dengan masyarakat dan keluarga (Tanshzil, S.W. ,2012).

Berdasarkan uraian dan permasalahan di atas, penulis tertarik dan ingin melakukan penelitian guna memperoleh kepastian dan kesesuaian antara yang terdapat pada teori dan yang terjadi pada kenyataan, maka penulis melakukan penelitian ini dengan judul "Sistem Dakwah Pondok Pesantren At-Tawazun Dalam Mengatasi Problematika Santri”, bagaimana perspektif sistem dakwah dalam pembinaan santri.

Dari latar belakang masalah di atas dapat di rumuskan beberapa masalah yaitu: Bagaimana proses sistem dakwah yang diterapkan pondok pesantren AtTawazun Kalijati Subang, strategi dakwah pondok pesantren At-Tawazun, dan Apa saja faktor pendukung dan penghambat sistem dakwah di pondok pesantren At-Tawazun dalam mengatasi problematika santri. Metode yang digunakan dalam penelitian ini adalah kualitatif studi kasus. Dengan analisis pengumpulan data melalui wawancara dengan pimpinan dan pengurus pondok pesantren AtTawazun, para santri,observasi, studi pustaka san studi dokumentasi.

\section{HASIL DAN PEMBAHASAN}

Teori yang dijadikan landasan dalam penelitian ini adalah proses sistem dakwah, pendidikan pesantren, dan akhlak. Maksud sistem adalah suatu rangkaian kegiatan yang sumbang menyumbang saling berkait menjelmakan urutan yang logis dan tetap terikat pada ikatan hubungan pada kegiatan masing-masing dan rangkaian secara menyeluruh (Moh. Ali Aziz, 2004:194). Dakwah sebagai sebuah sistem yang terdiri dari beberapa subsistem yang saling berhubungan. Dan dakwah secara kolektif (kelompok) yang dapat dianalisis dengan menggunakan teori sistem dakwah. Sistem dakwah dapat dibagi menjadi dua yaitu secara 
makro dan mikro. Secara makro, sistem dakwah merupakan subsistem sosio kultural didalam arti luas, sehingga analisa terhadapnya tidak dapat dilepaskan dengan subsistem ideologi, politik, pendidikan, ekonomi, tekhnologi dan budaya dalam arti sempit. Secara mikro dakwah Islam merupakan sistem yang berdiri sendiri sehingga analisa terhadapnya berdasarkan analisa faktor komponen yang membentuk sistem.

Sistem dakwah dapat juga di bagi sebutannya kedalam beberapa sistem, sebagai berikut:

Pertama, Subsistem (input) dapat berupa zat, energi, manusia dan informasi. Ia merupakan kekuatan yang menggerakan yang memberikan kepada sistem yang bersangkutan apa yang diperlukannya untuk beroperasi. Dalam konteks penelitian ini subsistem masukan memberikan daya beroperasinya sistem dakwah yang terdiri dari: masukan utama (rawinput), masukan sarana (instrumental input) dan masukan lingkungan(environmental input).

Input terdiri dari masukan utama (raw input) meliputi materi dakwah (AlQur'an, As-Sunnah dan ijtihad para ulama') dan manusia (da'i dan mad'u), masukan alat (instrumental input) meliputi metode dakwah dan logistik dakwah, dan masukan lingkungan (environmental input) yang berorientasi pada terciptanya masyarakat adil dan makmur yang diridhai Allah Swt.

Kedua, Subsistem konversi (Conversion) yaitu aktivitas yang mentransformasikan masukan menjadi keluaran. Ia dapat berupa sebuah mesin, seorang individu, sebuah komputer, sebuah bahan kimia atau peralatan, atau tugas- tugas yang dilaksanakan oleh sekelompok orang anggota organisasi. Dalam penelitian ini susbsistem proses (konversi) sistem dakwah terdiri dari: tujuan, qiyadah (kepemimpinan), tabligh, ta'dib, hijrah, amar ma'ruf nahyi mukar dan jihad (qital).Komponen konversi berfungsi untuk mengubah input menjadi output, merealisasikan ajaran Islam menjadi realitas sosio kultural yang diproses dalam kegiatan administrasi dakwah (organisasi, manajemen, leadership, komunikasi dakwah dan sebagainya).

Ketiga, Subsistem (output) merupakan hasil pengoperasian proses-proses atau dengan perkataan lain tujuan adanya sistem yang bersangkutan. Ada tiga kemungkinan pada output (keluaran) : kurang dari target harapan, sesuai dengan target harapan dan melebihi dari target harapan.Semua proses transformasi menyebabkan terbentuknya lebih dari satu macam tipe keluaran.Hasil akhir dari sistem dakwah Islam berdimensi ikhtiari dan hidayah. Oleh karena itu keluaran merupakan hasil subsistem proses dalam mentransformasikan Islam yang dibarengi dengan diterminasi akhir dari Allah yang disebut hidayah.

Keempat, Subsistem feedback adalah merupakan keluaran yang kembali 
menjadi masukan. Hal ini karena secara teoritis, sebuah sistem berjalan menurut siklus dan berdaur ulang (recycling). Proses datangnya kembali segala perolehan itu akan langsung berpengaruh terhadap sistemnya sendiri maupun melalui lingkungan terlebih dahulu dan demikian seterusnya. Balikan terdiri dari dua: balikan positif dan negatif. Balikan positif akan memperbesar ketahanan sistem. Balikan negatif adalahbalikan yang melawan arus, namun ini diperlukan sebagai wahana pencegah dini terhadap adanya penyimpangan-penyimpangan, bahan dan hal-hal yang bertentangan dengan tujuan. Sebuah sistem dapat bertahan justeru jika balikan negatifnya tetap berfungsi.

Kelima, Environment merupakan faktor lingkungan yang berfungsi sebagai kenyataan yang hendak diubah atau memberikan pengaruh terhadap sistem dakwah, terutama memberikan masukan permasalahan yang perlu dipecahkan yang menyangkut segala segi kehidupan (Amrullah Ahmad,1983:14).

Kajian tentang sistem dakwah dapat terlihat dari berlangsungnya rodakelembagaan atau organisasi. Pada teori sistem dakwah dapat dikembangkan melalui menajemen $6 \mathrm{M}$ yaitu pengurus (Man), pendanaan (Money),strategi managerial (Method), peralatan dan sarana (Machine), masyarakat mitra dakwah (Market), dan pesan dakwah (Material).

Pesantren selain sebagai lembaga pendidikan juga berfungsi sebagai lembaga social dan penyiaran agama Islam. Tempat ini juga sebagai salah satu tempat terjadinya intraksi sosial individu dengan kelompok untuk mengeratkan kebersamaan dan kerukunan masyarakat melalui hubungan pergaulan intraksi santri yang dilatar belakangi dengan nilai-nilai keislaman. Hal ini sejalan dengan yang diungkapkan oleh Mohammad Anif Arifani bahwa "Hubungan pergaulan interaksi sosial dalam aplikasinya dapat disisipi oleh semngat ajaran islam yang bias jadi akan melahirkan interaksi sosial model islam yang diatur sedemikian rupa dalam ajaran islam"(Arifani, $2008: 201$ )

Pondok Pesantren jika disandingkan dengan lembaga pendidikan yang pernah muncul di Indonesia, merupakan sistem pendidikan tertua saat ini dan dianggap sebagai produk budaya Indonesia yang indigenous. Pendidikan ini semula merupakan pendidikan agama Islam yang dimulai sejak munculnya masyarakat Islam di Nusantara pada abad ke-13 (M. Sulthon Masyhud dan Moh. Khusnurdilo, 2003:1).

Pondok pesantren dalam bacaan teknis merupakan suatu tempat yang dihuni oleh para santri. Pernyataan ini menunjukkan makna pentingnya ciri-ciri pondok pesantren sebagai sebuah lingkungan pendidikan yang integral (Abdurrahman Wahid,1999:13).

Pesantren adalah lembaga pendidikan tradisional Islam untk mempelajari, 
memahami,mendalami, menghayati, dan mengamalkan ajaran Islam dengan menekankan pentingnya moral keagamaan sebagai pedoman perilaku sehari-hari. Kata "tradisional" dalam batasan ini tidaklah merujuk dalam arti tetap tanpa mengalami penyesuaian, tetapi menunjuk bahwa lembaga ini hidup sejak ratusan tahun (300 - 400 tahun) yang lalu dan telah menjadi bagian yang mendalam dari sistem kehidupan sebagian besar umat Islam Indonesia, yang merupakan golongan mayoritas bangsa indonesia, dan telah mengalami perubahan dari masa kemasa, sesuai dengan perjalan hidup umat (Rofiq A.,dkk, 2005:24).

Pada mulanya tujuan pendidikan pesantren adalah (1) menyiapkan santri mendalami dan menguasai ilmu agama Islam atau lebih dikenal dengan tafaqquh $f i$ al-din yang diharapkan dapat mencetak kader-kader ulama dan turut mencerdaskan masyarakat Indonesia, (2) kemudian diikuti dengan tugas dakwah menyebarkan agama Islam, (3) sebagai benteng pertahanan umat dalam bidang akhlak. Sejalan dengan hal inilah, materi yang diajarkan di pondok pesantren semuanya terdiri dari materi agama yang langsung digali dari kitab-kitab klasik yang berbahasa Arab. Karena perkembangan zaman dan tuntutannya, pondok pesantren pun bertambah dikarenakan perkembangannya yang sangat signifikan. Dan (4) bertujuan untuk meningkatkan perkembangan masyarakat diberbagai sektor kehidupan. Namun sesungguhnya, tiga tujuan terakhir adalah manifestasidari hasil yang dicapai pada tujuan pertama, tafaqquh fi al-din. Tujuan ini punsemakin berkembang sesuai dengan tuntutan yang ada pada saat pondok pesantren itu didirikan (Departemen Agama RI, 2000:2).

Menurut Imam Ghazali dalam kitab "Ibya Ulumuddin" akhlak sifat yang tertanam dalam jiwa yang menimbulkan bermacam-macam perbuatan dengan gampang dan mudah tanpa memerlukan pemikiran dan pertimbangan. (Asmaran, 2002:2)

Dari pengertian diatas dapat disimpulkan bahwa akhlak adalah suatu kondisi dimana jiwa manusia yang sangat memerlukan pembinaan serta pendidikan ke arah yang lebih baik, karena kondisi ini sangat rawan dan mudah dipengaruhi oleh lingkungan sekitar kita, atau mudah tercemar oleh berbagai bentuk kebudayaan yang masuk kedalam lingkungan kita terutama pada remaja.

Secara historis Pondok Pesantren At-Tawazun lahir sejak pertama kali KH. Musyfiq Amrullah menerima tanah wakaf sebesar $4714 \mathrm{~m} 2$ oleh wakif yang bernama H. Uzer Chuzaeri pada tahun 2001, lalu dimulailah pelatakan batu pertama dan pembangunan pondok pesantren At-Tawazun pada bulan juli 2002 sya'ban $1423 \mathrm{H}$. Areal tanah wakaf bertambah sekitar $480 \mathrm{~m} 2$ dari keluarga Alm Bapak M Jaja dan Ibu Siti Rohaeni dan $3490 \mathrm{~m} 2$ dari warga masyarakat. Dan juga perluasan tanah wakaf $560 \mathrm{~m} 2,700 \mathrm{~m} 2,336 \mathrm{~m} 2,84 \mathrm{~m} 2$ dan $280 \mathrm{~m} 2$ hasil uang wakaf sendiri. Dengan total jumlah tanah yang dimiliki Pondok Pesantren 
At-Tawazun sekitar $10.644 \mathrm{~m} 2$. Pondok Pesantren At-Tawazun pertama kali membuka lembaga pendidikan tingkat Mts At-Tawazun pada tahun 2003 dengan jumlah santri yang mukin hanya 7 santri, ditambah pengajian salafiah malah hari warga sekitar pondok sebanyak 25 santri.

Visi Pondok Pesantren At-Tawazun adalah "terwujudnya lembaga pendidikanyangmenghasilkan generasi sebagai Abdullah dan Khalifatullah serta Khairunnaas Anfa'ubum linnas". Dengan misi yaitu: (1) Mewujudkan pesantrenyang dapat membudayakan sipat disiplin, demokratis, dan komunikatif antara unsur di lingkungan pesantren, (2) mempertahankan nilai-nilai terdahulu yang baik dan mengambil nilai-nilai kekinian yang lebih baik, (3) membentuk generasi ulama yang Intelek dan Intelek yang ulama, (4) membudayakan generasi yang berilmu amaliyah dan beramal ilmiyah dan berakhlaqul karimah.

At-Tawazun yang artinya adalah keseimbangan, pondok pesantren ini menerapkan tiga sistem pendidikan dengan memadukan sistem pendidikan modern (bahasa arab-inggris dan tabfidy, salafiah, kitab kuning dan kurikulum pemerintah), yang kami sebut dengan sistem "Trisulapendidikan". Kurikulum yang menjadi ruh sekaligus kekuatan pondok senantiasa direvisi serta diperbaharui, sesuai dengan tuntutan dan perkembangan pendidikan dengan tanpa menapikan nilai-nilai agama serta tradisi kepesantrenan. Usaha ini mendapat sambutan baik dan hangat dari berbagai kalangan masyarakat sehingga banyak yang menitipkan dan mempercayakan pendidikan putra-putrinya di Pondok Pesantren At-Tawazun mengemban amanah dan tanggung jawab pendidikan yang begitu berat dengan jumlah santriawan dan santriwati yang mencapai 700an, oleh sebab itu disiplin dalam pengasuhan, pembinaan serta pendidikan dilakukan dengan sistem 24 jam serta melibatkan guru-guru yang ahli dan berpengalaman dibidangnya.

\section{Sistem dakwah yang diterapkan pondokpesantren At-Tawazun Kalijati Subang}

Sistem adalah suatu rangkaian kegiatan yang sambung menyumbang saling berkait menjelmakan urutan yang logis dan tetap terikat pada ikatan hubungan pada kegiatan masing-masing dan rangkaian secara menyeluruh (Moh. Ali Aziz, 2004:194). Memahami esensi dari makna itu sendiri, kegiatan dakwah sering dipahami sebagai upaya untuk memberikan solusi Islam terhadap berbagai masalah dalam kehidupan. Oleh sebab itu, harus bisa memilih cara atau metode yang tepat agar dakwah aktual, faktual dan konstekstual. Aktual dalam arti memecahkan masalah yang kekinian dan hangat ditengah masyarakat. Faktual dalam arti nyata, serta konstektual dalam arti relevan dan menyangkut problema yang sedang dihadapi masyarakat.

Pondok pesantren At-Tawazun dalam mengatasi problematika santri dan menyiarkan dakwah terhadap peserta didik di pesantren maupun masyarakat 
sekitar yaitu menggunakan beberapa metode atau cara berdakwah dengan tujuan dakwah yang disyiarkan dapat diterima oleh mad'u yang menjadi sasarannya. Dalam penyampaian dakwahnya dikalangan santri, pondok pesantren AtTawazun menerapkan beberapa sistem dakwah yang di implementasikan terhadap beberapa metode, guna mengatasi problematika akhlak dikalangan santri, seperti kenakalan-kenakalan yang dilakukan oleh santri, karena tidak jarang pada zaman sekarang ini berdakwah harus menerapkan metode-metode dakwah yang efektif.

Adapun sistem dakwah yang diterapkan pondok pesantren At-Tawazun dalam mengatasi kenakalan santri yaitu dengan menggunakan sistem terbuka yang di implementasikan oleh dalam metode dakwah Mauidzah Hasanah (Wawancara dengan Ust. Teguh Rahmat Sidik sebagai ketua sekretariat pesantren At-Tawazun pada tanggal 17 Mei 2018).

Metode dakwah mau'idzah hasanah yang diterapkan pondok pesantren AtTawazun termasuk kedalam empat ungkapan yaitu :

Pertama Nasihat, merupakan salah satu cara bahasa dari al-mau'izah al-hasanah yang bertujuan mengingatkan bahwa segala perbuatan pasti ada sanksi dan akibatnya. Secara terminologi, nasihat adalah memerintahkan, melarang, atau menganjurkan yang dibarengi motivasi dan ancaman.

Allah berfirman dalam Al-Qur'an surah Al-Ashr ayat 1-3 tentang nasihat yang artinya:

"Demi masa. Sesunggubnya manusia itu benar-benar dalam kerugian, kecuali orangorang yang beriman dan mengerjakan amal saleh dan nasehat menasehati supaya mentaati kebenaran dan nasehat menasehati supaya menetapi kesabaran" (Q.S Al-Ashr ayat 1-3).

Dalam mengatasi masalah-masalah santri yang melenceng dari tata tertib atau aturan yang telah ditetapkan dan perilaku yang tidak sesuai ataupun tingkah yang tidak sewajarnya dimiliki seorang santri. pondok pesantren At-Tawazun senantiasa memberikan nasehat yang dibarengi dengan motivasi juga mengatakan sesuatu yang benar dengan cara melunakkan hati mereka agar mereka senantiasa tidak melakukan hal- hal yang berbau negatif.

Dari segi penerapannya, pondok pesantren At-Tawazun yaitu dengan cara, pimpinan dan dewan guru menghimbau kepada santri yang melanggar peraturan pesantren yang telah ditetapkan dan disepakati secara bersama-sama. Nasehat itu biasanya dilakukan dirumah pimpinan atau diruang kantor dengan cara memanggil santri itu untuk datang kerumahnya (Wawancara dengan Ust. Teguh Rahmat Sidik sebagai ketua sekretariat pesantren At-Tawazun pada tanggal 17 Mei 2018).

Nasihat itu bisa dilakukan dimana saja selagi melihat adanya kemungkaran yang ada dimuka bumi ini. Pentingnya nasihat itu diberikan kepada santri agar segala tingkah laku dan perbuatannya sesuai dengan agama Islam. 
Kedua Tabsyir, secara bahasa berasal dari kata basyara yang mempunyai arti memperhatikan, merasa senang. Adapun tabsyir dalam istilah dakwah adalah penyampaian dakwah yang berisi kabar-kabar yang menggembirakan bagi orangorang yang mengikuti dakwah.

Dari segi penerapannya, pondok pesantren memberikan suatu informasi kepada santri, yaitu dengan menggalakkan mereka senantiasa hidup sehat, disiplin, dan tidak pernah bosan untuk belajar agama, karena dari pihak pesantren akan menilai dan memberikan reward yaitu berbentuk penghargaan yang biasanya akan diberikan pada selama satu bulan sekali, dan juga dari pihak pesantren mengecek kebersihan asrama, kemudian mengumumkan asramaasrama yang bersih yang nantinya akan diberikan suatu penghargaan (Wawancara dengan Ust. Teguh Rahmat Sidik sebagai ketua sekretariat pesantren AtTawazun pada tanggal 17 Mei 2018).

Pentingnya kegiatan di atas bertujuan untuk menguatkan, memperkokoh keimanan, memberikan harapan, menumbuhkan semangat mereka untuk beramal, dan santri mencintai kebersihan.

Ketiga Tandzir, menurut istilah dakwah adalah menyampaikan dakwah dimana isinya berupa peringatan terhadap manusia tentang adanya kehidupan akhirat dengan segala konsekuensinya (Munzier Saputra, 2006:103).

Dalam penerapan di pondok pesantren At-Tawazun yaitu adanya struktur organisasi yaitu bagian keamanan yang mengawasi santri, apabila ada santri yang melanggar peraturan seperti tidak shalat berjamaah, merokok, dan lain-lain maka akan diberi hukuman atau sanksi yang berupa menghafal surah-surah penting, bentuk hukuman seperti ini dibuat supaya santri tidak mengulangi lagi apa yang diperbuat. Pentingnya hukuman ini diberikan agar santri bisa disiplin dalam menjalankan peraturan-peraturan yang ada di pesantren dengan baik dan benar (Wawancara dengan Ust Asep Usman, Guru Pesantren, Tanggal 18 Juni 2018).

Keempat Kisah, Pondok pesantren At-Tawazun dalam menerapkan dakwah kepada santrinya yaitu dengan cara kyai menceritakan pengalamannya ketika beliau menjadi murid, berpesan kepada santri-santrinya agar tidak bermalas-malasan dalam menuntut ilmu dan mematuhi segala peraturan yang ada di pesantren.

Pentingnya seorang kyai menceritakan kisah ini agar santri dapat mengikuti jejak para guru-gurunya.

Berdasarkan hasil wawancara diatas dapat disimpulkan dimana sistem dakwah yang diterapkan pesantren At-Tawazun dalam membina santri yaitu sistem terbuka. Adapun tahapan proses dari sistem tersebut memuat lima langkah yang bergerak diatas tujuan proses sehingga mencapai tujuan yang diharapan. Lima langkah kerja dalam tahap proses yaitu:

Pertama Input, dalam konteks penelitian di pondok pesantren At-Tawazun ini subsistem masukan memberikan daya beroperasinya sistem dakwah yang 
terdiri dari:

(1) masukan utama (raw input) meliputi materi dakwah (Al-Qur'an, AsSunnah dan ijtihad para ulama') dan manusia (da'i dan mad'u), (2) masukan alat (instrumental input) meliputi metode dakwah dan logistik dakwah, dan (3) masukan lingkungan (environmental input) yang berorientasi pada terciptanya masyarakat adil dan makmur yang diridhai Allah Swt.

Kedua Conversion, Subsistem (konversi) yaitu aktivitas yang mentransformasikan masukan menjadi keluaran. Ia dapat berupa sebuah mesin, seorang individu, sebuah komputer, sebuah bahan kimia atau peralatan, atau tugas- tugas yang dilaksanakan oleh sekelompok orang anggota organisasi. Namun demikian, dalam beberapa situasi, transformasi tidak dapat diketahui secara detail karena transformasi bersifat kompleks. Dalam penelitian ini subsusbsistem proses (konversi) sistem dakwah terdiri dari : tujuan, qiyadah (kepemimpinan), tabligh, ta'dib, bijrah, amar ma'ruf nabyi mukar dan jihad (qital). Sub-subsistem ini merupakan perwujudan dari fungsi sistem dakwah dan merupakan wilayah ikhtiar dakwah karena hasil yang diharapkan akan sangat ditentukan dari tindakan dakwah dalam melaksanakan proses transformasi ini.

Ketiga Output, merupakan hasil yang telah dicapai. Keluaran juga dihadapkan pada keluaran harapan dan keluaran kenyataan. Ada tiga kemungkinan pada output (keluaran) : kurang dari target harapan, sesuai dengan target harapan dan melebihi dari target harapan.

Semua proses transformasi menyebabkan terbentuknya lebih dari satu macam tipe keluaran. Terkait dengan penelitian ini maka keluaran sistem dakwah mencakup terwujudnya Islam dalam kehidupan pribadi, keluarga, jama'ah, masyarakat dan negara (daulah) sehingga Islam menjadi rahmat seluruh alam. Keluaran akan memberikan pengaruh dan perubahan lingkungan. Hasil akhir sistem dakwah Islam berdimensi ikhtiari dan hidayah. Oleh karena itu keluaran merupakan hasil subsistem proses dalam mentransformasikan Islam yang dibarengi dengan diterminasi akhir dari Allah yang disebut bidayah.

Keempat Feedback, Dalam sebuah proses, apa pun output yang dihasilkan selalu membawa dampak (impact), baik dalam skala kecil maupun besar. Dampak memberikan nilai pada keluaran. Keluaran boleh dianggap kecil, tapi jika dampaknya besar maka nilainya pun menjadi besar. Dampak bisa saja nampak dalam jangka waktu yang pendek maupun jangka panjang.

Proses datangnya kembali segala perolehan itu akan langsung berpengaruh terhadap sistemnya sendiri maupun melalui lingkungan terlebih dahulu dan demikian seterusnya. Balikan terdiri dari dua: balikan positif dan negatif. Balikan positif akan memperbesar ketahanan sistem. Balikan negatif adalah balikan yang melawan arus, namun hal ini diperlukan sebagai wahana pencegah dini terhadap adanya penyimpangan-penyimpangan, bahan dan hal-hal yang bertentangan 
dengan tujuan. Sebuah sistem dapat bertahan justru jika balikan negatifnya tetap berfungsi.

Dalam penelitian ini balikan sistem dakwah terdiri dari : balikan positif (informasi dan sikap mad'u berupa dukungan), balikan negatif (informasi dan sikap mad'u berupa hambatan) dan sikap netral mad'u.

Kelima Environment, faktor lingkungan berfungsi sebagai kenyataan yang hendak diubah atau memberikan pengaruh terhadap sistem dakwah, terutama memberikan masukan permasalahan yang perlu dipecahkan yang menyangkut segala segi kehidupan.

Seperti pondok pesantren At-Tawazun ini yang dekat dengan kehidupan pasar dan juga aktivitas masyarakat, sangat mempengaruhi terhadap pola prilaku santri. Misalnya santri sering boros karena selalu berbelanja, bahkan sampai nekat bolos dari pesantren. Dan juga lingkungan pergaulan pasar cukup keras, ini menjati fokus utama untuk memberikan palajaran mental agar santri tidak terlibat dalam kegiatan kekerasan.

\section{Strategi dakwah pondok pesantren At-Tawazun dalam penyelesaian problematika santri}

Strategi dakwah merupakan cara, siasat atau taktik untuk melakukan suatu rencana yang telah disesuaikan dengan sasaran yang cermat guna mencapai tujuan dakwah. Dalam menyelesaikan masalah-masalah di kalangan santri, pondok pesantren At-Tawazun senantiasa menerapkan beberapa strategi kepada santri agar santri bisa mematuhi peraturan-peraturan yang ditetapkan pesantren.

Menurut hasil wawancara dengan Ust. Teguh Rahmat Sidik sebagai ketua sekretariat pesantren At-Tawazun pada tanggal 17 Mei 2018, pondok pesantren At-Tawazun dalam hal mengatasi santri yang melanggar tata tertib pesantren yaitu ada beberapa strategi yang di terapkan. Menurut beliau strategi yang di terapkan dan juga sanksi yang diberikan kepada santri itu tidak dalam berbentuk fisik tetapi lebih kepada nasehat dan motivasi, alasannya jika santri dihukum dalam bentuk fisik, maka santri tersebut akan bergejolak, karena rata- rata santri pondok pesantren At-Tawazun masih berada ditingkat remaja (Wawancara dengan Ust. Teguh Rahmat Sidik pada tanggal 17 Mei 2018).

Adapun beberapa strategi yang dijalankan pondok pesantren dalam menyelesaikan problematika santri yaitu:

(1) Memberikan hukuman kepada santri dalam bentuk hafalan, yang di maksud dari strategi memberikan hukuman kepada santri dalam bentuk hafalan yang di terapkan pondok pesantren At-Tawazun yaitu, jika ada santri yang melanggar tata tertib pesantren misalnya membawa handphone, merokok, tidak shalat berjamaah, dan sebagainya, maka dari pihak pesantren akan memberikan suatu materi kepada santri untuk dihafal dan akan di setor hafalan tersebut pada malam muhadharah yaitu setiap malam jum'at (Wawancara dengan Ustzh Dzikrina 
sebagai Guru Pesantren, Tanggal 17 Mei 2018.).

(2) Memperketat controling para guru dan piket, kegiatan ini untuk mengatasi problematika dikalangan santri, pondok di pesantren At-Tawazun Memberlakukan sistem controling yang ketat terhadap santri, yang diterapkan kepada guru maupun piket. Menurut hasil wawancara dengan Ust. Teguh Rahmat Sidik hal ini diterapkan agar santri bisa lebih disiplin dan bisa mematuhi segala peraturan pesantren (Wawancara dengan Ust. Teguh Rahmat Sidik pada tanggal 17 Mei 2018).

(3) Melakukan razia tanpa sepengetahuan santri, Pesantren At-Tawazun secara tidak beraturan waktu akan melakukan razia kepada santri, biasanya razia tersebut dalam bentuk melakukan pengoperasian tiap-tiap asrama. Menurut beliau, strategi ini sangat ampuh dilakukan karena dalam penerapannya tanpa sepengetahuan santri. Dalam melakukan razia tersebut sangat banyak santri yang kedapatan melanggar tata terbit pesantren seperti kedapatan membawa hp, rokok dan sebagainya (Wawancara dengan Ust Asep Usman, Guru Pesantren, Tanggal 18 Mei 2018).

Bagi santri yang kedapatan membawa sesuatu yang melanggar tata tertib pesantren, maka barang tersebut akan disita oleh pihak pesantren, dan akan dipulangkan barang tersebut langsung kepada orang tua atau wali santri dengan memberikan surat undagan untuk hadir di pesantren.

(4) Menanamkan akidah pada para santri secara benar, penerapan aqidah di Pondok Pesantren At-Tawazun dilaksanakan dengan cara pemilihan mata pelajaran yang berkualitas tentang materi-materi syariat Islam, pengajian ini dilaksanakan setiap hari kecuali hari Jum'at dan Sabtu, pengajian tersebut mulai pukul 08.00-11.50 WIB khususnya di kelas, dan setiap malam yang bertempat di musholla pukul 18.30 WIB hingga selesai dengan kajian kitab yang sesuai dengan tingkatan kelas para santri. Kajian kitab tersebut meliputi kitab; Matan bina wal asas, Maniatul musholli, Pati Faridatul faroid, Fathul qoribul mujib, Matan al-ajurumiah, supaya santri mampu memahami secara benar perintahperintah syariat dan larangan-larangan syariat dalam Al-Qur'an serta hadist. Dalam setiap kali pembelajaran, para santri bias memahami materi yang telah disampaikan para ustadz/ ustadzah secara teoritis dan diterapkan di kehidupan santri sehari-hari secara praktis, sehingga akan membentuk karakter santri secara benar sesuai syariat islam.

(5) Membentuk pendidikan Aklakul karimahmerupakan pembelajaran untuk meningkatkan karakter/perilaku individu maupun kelompok dalam bermasyarakat baik dalam pondok pesantren maupun di masyarakat. Jadi membentuk pendidikan Aklakul karimah sangat penting terhadap para santri karena santri merupakan makhluk yang bersosial dan saling meminta pertolongan kepada orang lain(Wawancara dengan Ustzh Dzikrina sebagai Guru 
Pesantren, Tanggal 17 Mei 2018).

Dalam pembentukan akhlakul karimah yang diterapkan Pondok Pesantren At-Tawazun dilaksanakan setiap sore pukul 16.00-17.30 WIB. Dalam mujadalah, para santri dituntut berdiskusi materi pelajaran sebelumnya, saling berdebat dengan menyampaikan pendapat masing-masing secara baik dan sopan dengan saling menghargai pendapat yang lain, supaya lebih mendalami pemahaman materi yang telah diajarkan para ustadz/uztadazah.Setiap tahun Pondok Pesantren At-Tawazun akan mengadakan majelis pertemuan para alumni yang bertempat di dalam Pondok Pesantren At-Tawazun sendiri maupun di luar Pondok Pesantren, supaya mereka bertambah akrab sesama santri sendiri dan akrab sesama para ustadz/ustadzah yang telah memberikan ilmu pengetahuan kepadanya. Para ustadz/ustadzah dan pengurus Pondok Pesantren tidak ingin jika santri yang sudah lulus dari Pondok Pesantren tidak lagi berkunjung ke Pondok Pesantren At-Tawazun.

Bedasarkan hasil wawancara diatas baik dengan pimpinan maupun dewan guru dalam hal menyelesaikan problematika dikalangan santri. Pondok pesantren AtTawazun dalam menyelesaikan problematika dikalangan santri yaitu tidak memberikan sanksi atau hukuman kepada santri dalam bentuk fisik akan tetapi lebih kepada materi hafalan yang diberikan.

\section{Faktor Pendukung Dan Penghambat Sistem Dakwah Pondok Pesantren At-Tawazun Dalam Mengatasi Problematika Santri}

Melihat langsung dilokasi penelitian, ada beberapa hal yang peneliti temukan, dan juga hasil wawancara dengan pimpinan dan ustadz-ustadzah diantaranya ialah faktor pendukung dan penghambat sistem dakwah pondok pesantren AtTawazun dalam mengatasi permasalahan yang ada pada santri, yaitu:

Pertama Faktor pendukung sistem dakwah pondok pesantren At-Tawazun dalam mengatasi problematika santri

(1) Adanya pengaruh seorang Abi, Kiayi atau biasa di panggil Abi tidak hanya mempunyai pengaruh besar terhadap pesantren, namun juga terhadap mesyarakat sekitar karena selain sebagai pengasuh pondok pesantren, Abi juga menjadi tokoh agama dan tokoh masyarakat yang budi pekertinya selalu menjadi cermin suri tauladan bagi masyarakat.

Sehingga seorang Abi apabila bermaksud untuk menjadikan pesantrennya berkembang dan menginginkan masyarakatnya menjadi masyarakat yang agamis dan berakhlak mulia, maka selain harus mempunyai bekal ilmu pengetahuan dan agama yang tinggi dan pengetahuan yang luas, Abi juga harus mempunyai akhlak yang baik, karena dengan akhlak yang baik dan mulia akan timbul karismatik dan wibawa dalam dirinya dan selalu di segani oleh para santri. Dengan rasa segan itu akan membuat para santri selalu mengikuti apa yang telah disampaikan dan diperintahkan olehnya, sehingga hal ini akan mempermudah terlaksananya suatu 
program yang ingin dicapai.

Begitu juga halnya pada pondok pesantren At-Tawazun, beliau memiliki pengaruh yang sangat besar terhadap santri, dimana beliau senantiasa memberikan nasehat dan motivasi kepada santri-santrinya agar tidak bermalasmasalan dalam menuntut ilmu dan senantiasa hidup disiplin (Wawancara dengan Ust. Teguh Rahmat Sidik pada Tanggal 17 Mei 2018).

(2) Adanya jadwal piket yang jelas, demi jalannya sistem dakwah pondok pesantren A-Twawazun untuk mengatasi permasalahan dikalangan santri, pesantren At-Tawazun menerapkan jadwal piket yang jelas agar dapat mengotrol santri (Wawancara dengan Ust Asep Usman, Guru Pesantren, Tanggal 18 Mei 2018).

Adapun tugas yang dibebankan kepada piket yaitu untuk mencatat namanama santri yang tidak mengikuti shalat berjamaah, yang keluar malam tanpa izin dari piket dan pihak pesantren, dalam konteks santri yang melanggar peraturanperaturan pesantren.

(3) Adanya kerjasama dengan tokoh masyarakat, dalam hal mengatasi santri yang melanggar tata tertib pesantren, pihak pesantren bekerja sama dengan tokoh-tokoh masyarakat dalam hal mengontrol santri, seperti memperingati santri-santri yang melanggar tata tertib pesantren, dan juga tokoh masyarakat senatiasa hadir dalam rapat yang diadakan oleh pihak pesantren (Wawancara dengan Ust Asep Usman, Guru Pesantren, Tanggal 18 Mei 2018).

Kedua Faktor penghambat sistem dakwah pondok pesantren At-Tawazun dalam mengatasi problematika santri

Menurut hasil dari observasi dan wawancara, pondok pesantren Bustanuddin dalam hal menerapkan metode dakwah kepada santri yang melanggar peraturan pesantren memiliki beberapa kendala dan hambatan.Adapun beberapa kendala yang dimiliki antara lain sebagai berikut:

(1) Minimnya guru yang tinggal dilokasi pesantren, merupakan salah satu faktor penghambat yang paling besar, dimana para guru tidak sepenuhnya mengontrol santri. Hanya kepada seorang kyai yang dapat mengontrol santri 24 jam, karena pak kyai berdomisili atau bertempat tinggal di lokasi pesantren (Wawancara dengan Ust. Teguh Rahmat Sidik pada tanggal 17 Mei 2018).

(2) Pengaruh lingkungan dan teman sebaya yang bukan santri, Pondok pesantren At-Tawazun merupakan pesantren yang terletak dekat dengan jalan nasional dan berada di tengah-tengah keramaian lingkungan mmasyarakatdan pasar kalijati. Santri dari pesantren At-Taazun kebanyakan dari kalangan remaja yang mayoritas dari desa itu sendiri dan minoritas remaja desa sekitarnya dan dari luar wilayah Subang. Dimana masa remaja adalah masa yang sangat rentan terhadap pengaruh budaya luar yang bersifat negatif. Dari pengaruh lingkungan dan teman sebaya yang kebanyakan santri mulai tidak mematuhi tata tertib yang 
berlaku di pesantren. Yang membuat pegaruh lingkungan dan teman sebaya dikarenakan santri pondok pesantren At-Tawazun masih dalam jenjang pendidikan baik itu SMP maupun SMA (Wawancara dengan Ust. Teguh Rahmat Sidik pada tanggal 17 Mei 2018).

(3) Kurangnya kepedulian orang tua terhadap anaknya, yang menjadi hambatan jalannya dakwah pesantren At-Tawazun yaitu kebanyakan para orang tua santri sangat kurang kepeduliannya terhadap anak-anak mereka, kebanyakan orang tua, setelah mengantarkan anaknya kepesantren seolah-olah lepas tanggung jawab orang tua terhadap anak dan hanya kepada pesantren yang bertanggung jawab sepenuhnya terhadap tingkah laku dan perbuatan anaknya. Padahal lingkungan keluarga merupakan tempat pertama anak itu mengenal sesuatu yang buruk dan yang baik. Dikarenakan para orangtua mereka sibuk dengan pekerjaannya baik itu keladang, kesawah maupun kekantor (Wawancara dengan Ust. Teguh Rahmat Sidik pada tanggal 17 Mei 2018).

Dari pernyataan di atas, ada beberapa yang menjadi faktor pendukung dan penghabat terhadap jalannya dakwah pondok pesantren At-Tawazun. Dilihat dari segi faktor pendukungnya pesantren At-Tawazun memiliki seorang kyai dan Guru yang sangat berperan aktif dalam memotivasi santri-santrinya agar senantiasa menjadi santri yang berakhlak mulia. Dari segi kontrol terhadap santri, pesantren At-Tawazun memberlakukan jadwal piket yang jelas agar dalam penerapan peraturan dapat berjalan lancar seperti yang diharapkan, dan juga adanya kerjasama dengan masyarakat yang turut mengontrol santri.

Ditinjau dari faktor penghambatnya, pondok pesantren At-Tawazun memiliki beberapa kendala yaitu minimnya guru yang tinggal dilokasi pesantren, ini merupakan kendala bagi pesantren At-Tawazun karena tidak bisa mengontrol santri dengan sepenuhnya, lingkungan dan teman sebaya juga merupakan hal yang sangat berpengaruh terhadap santri dalam mematuhi peraturan yang telah ditetapkan dan juga kurangnya kepedulian orang tua terhadap anak mereka, kepedulian orang tua terhadap anak sangat berpengaruh besar dalam membimbing mereka agar anak senantiasa hidup disiplin dan sebagainya dikarenakan lingkungan keluarga merupakan tempat pertama dimana seorang anak mendapatkan didikan.

\section{PENUTUP}

Hasil penelitian ini menunjukkan bahwa keberadaan pondok pesantren AtTawazun dirasakan cukup besar manfaatnya oleh orang tua maupun masyarakat. Lembaga dakwah dan pendidikan ini telah ikut berkontribusi dalam menanggulangi masalah sosial dan kenakalan remaja yang semakin rumit, sehingga mampu memberikan lulusan santri yang brakhlak, berbudi luhur dan mampu mengamalkan ilmunya di masyarakat. Lebih dari itu, kehadiran pondok pesantren At-Tawazun diharapkan dapat mengatasi akulturasi budaya yang 
menyimpang di era sekarang ini. Sehingga semangat generasi muda kita dapat disalurkan terhadak hal-hal positif.

Pondok pesantren At-Tawazun dalam mengatasi problematika santri menerapkan sistem dakwah terbuka, dengan langkah-langkah sebagai berikut:

Pertaman input, terdiri dari: (1) masukan utama (raw input) meliputi materi dakwah (Al-Qur'an, As-Sunnah dan ijtihad para ulama') dan manusia (da'i dan mad'u), (2) masukan alat (instrumental input) meliputi metode dakwah dan logistik dakwah, dan (3) masukan lingkungan (environmental input) yang berorientasi pada terciptanya masyarakat adil dan makmur yang diridhai Allah Swt.

Kedua conversion, dalam penelitian ini proses (konversi) sistem dakwah terdiri dari : tujuan, qiyadah (kepemimpinan), tabligh, ta'dib, hijrah, amar ma'ruf nabyi mukar dan jihad (qital).

Ketiga output (keluaran) terkait dengan penelitian ini maka keluaran sistem dakwah mencakup terwujudnya Islam dalam kehidupan pribadi, keluarga, jama'ah, masyarakat dan negara (daulah) sehingga Islam menjadi rahmat seluruh alam dan memberikan pengaruh dan perubahan lingkungan sekitar.

Keempat feedback (balikan), sistem dakwah dalam penelitian ini terdiri dari: balikan positif (informasi dan sikap mad'u berupa dukungan), balikan negatif (informasi dan sikap mad'u berupa hambatan) dan sikap netral mad'u.

Kelima environment, faktor lingkungan pondok pesantren At-Tawazun ini yang dekat dengan kehidupan pasar dan juga aktivitas masyarakat, sangat mempengaruhi terhadap pola prilaku santri. Misalnya santri sering boros karena selalu berbelanja, bahkan sampai nekat bolos dari pesantren. Dan juga lingkungan pergaulan pasar cukup keras, ini menjati fokus utama untuk memberikan palajaran mental agar santri tidak terlibat dalam kegiatan kekerasan.

Strategi dakwah Pondok Pesantren At-Tawazun dalam menerapkan pembinaan kedisiplinan yaitu memberikan hukuman kepada santri dalam bentuk hafalan, memperketat controling para guru dan piket, melakukan razia tanpa sepengetahuan santri, menanamkan akidah pada para santri secara benar,dan menanamkan pendidikan akblak al-karimah. Strategi ini berguna untuk menerapkan hukum dan kedisiplinan tanpa melakukan tindakan kekerasan yang bertentangan dengan hukum.

Faktor pendukung dalam pelaksanaan dakwah di pondok Pesantren AtTawazun bertitik pada tanggungjawab dan loyalitas dari para pengurus dan ustadz-ustadzah Pondok Pesantren At-Tawazun untuk tetap mengabdi dan berdakwah baik di lingkungan Pondok Pesantren sendiri maupun di masyarakat di sekitarnya, sehingga dakwah islam semakin kuat dan maju.

Sedangkan faktor penghambat pelaksanaan dakwah pondok pesantren AtTawazun ada pada lingkungan dakwah yang dekat dengan pasar serta berbagai problematika kehidupannya. Sehingga pergaulan santri yang mayoritas masih 
remaja ikut terlibat didalamnya seperti kekerasan dan lain-lain.

\section{DAFTAR PUSTAKA}

Ahmad, A.(1983). Dakwah Islam dan Perubahan Sosial, Yogyakarta: Primaduta.

Ardi, D. M. (2015). Psikologi Dakwah. Bandung: Mimbar Pustaka.

Arifani, M. A. (2008). Eksistensi Budaya Lokal Sebagai Model Pengembangan

Dakwah; Pendekatan Sosiologis dalam Ilmu Dakwah: Academic Journal for Homiletic Studies, 4(12),193-213.

Asmaran, (2002). Studi Akblak, Jakarta: PT. Raya Grafindo Persada.

Aziz,M.A. (2004). Ilmu Dakwah. Jakarta: Kencana

Departemen Agama Republik Indonesia. (2007) Al-Qur"an dan Terjemahannya, Bandung: PT Sygma Examedia Arkanleema.

Fitriyah dkk. (2018). Eksistensi Pesantren Dalam Pembentukan Kepribadian Santri. Palapa: Jurnal Studi Keislaman dan Ilmu Pendidikan , 6(2), 155-173.

Hotifah, Y. (2015). Penyelesaian Permasalahan Santri melalui Peer Helping Indigenius. Ilmu Pendidikan, 42(2), 132-138

Lubis dkk. (2018). Pembinaan Mental Spiritual Santri di Pesantren Modern Unggulan Terpadu Darul Mursyid Kabupaten Tapanuli Selatan. ANALYTICA ISLAMICA, 7 (2), 253-271Mastuhu. (1995). Dinamika Sistem Pendidikan, Jakarta, INK.

Rizal, M. dkk. (2018). Model Pendidikan Akhlaq Santri di Pesantren dalam meningkatkan Akhlaq Siswa Di Kabupaten Bireuen. Nadwa : Jurnal Pendidikan Islam, 12 (1), 89-116.

Rofiq, A.,dkk. (2005) Pemberdayaan Pesantren Menuju Kemandirian danProfesionalismeSantridengan MetodeDaurabKebudayaan. Yogyakarta: PT Lkis Printing Cemerlang.

Sulton, M. \& Khusnuridlo, M. (2006) Manajemen Pondok Pesantren dalamPrespektif Global. Yogyakarta: Laksbang Pres Sindo.

Suparta,M. (2006). Metode Dakwah, Jakarta: PT. Semesta.

Tajiri, Hajir. (2015). Integrasi Kognitif dan Perilaku dalam Pola Penanaman Disiplin Santri di Pesantren. Al-Tahrir: Jurnal Pemikiran Islam , 11 (2), 415432 .

Tajiri, H. (2016). Kendali Diri Perilaku Seksual dan Pengembangannya melalui Konseling pada Siswa Madrasah Aliyah di Kabupaten Bandung. Cendekia, 14 (1), 91-106.

Tanshzil, S.W. (2012). Model Pembinaan Pendidikan Karakter pada Lingkungan Pondok Pesantren dalam Membangun Kemandirian dan 
Disiplin Santri (Sebuah kajian pengembangan Pendidikan Kewarganegaraan). Jurnal Penelitian Pendidikan,13(2), 1-18.

Wahid, A.(1999). Pesantren Masa Depan Wacana Pemberdayaan dan TransformasiPesantren, Bandung: Pustaka Hidayah. 